\title{
Genetic diversity assessment of Hemibagrus nemurus from rivers in Java Island, Indonesia using COI gene
}

\author{
AGUS NURYANTO ${ }^{1, \boldsymbol{}}$, NUNUNG KOMALAWATI ${ }^{2}$, SUGIHARTO $^{1}$ \\ ${ }^{1}$ Faculty of Biology, Universitas Jenderal Soedirman. Jl. Dr. Soeparno 63, Purwokerto, Banyumas 53122, Central Java, Indonesia \\ Tel.: +62-281-638794, Fax.: +62-281-631700, `email: anuryanto2003@yahoo.com \\ ${ }^{2}$ Faculty of Fisheries and Marine Science, Universitas Jenderal Soedirman. J1. Dr. Soeparno 63, Purwokerto, Banyumas 53122, Central Java, Indonesia
}

Manuscript received: 21 May 2019. Revision accepted: 28 August 2019.

\begin{abstract}
Nuryanto A, Komalawati N, Sugiharto. 2019. Genetic diversity assessment of Hemibagrus nemurus from rivers in Java Island, Indonesia using COI gene. Biodiversitas 20: 2707-2717. Green catfish (Hemibagrus nemurus) is a popular freshwater fish that highly exploited in almost all the rivers in Java Island. The exploited population tends to have low genetic diversity. Meanwhile, separated populations might lead to a genetic difference among the river populations. This study aims to investigate the genetic diversity and population variation of $H$. nemurus collected at eleven rivers across Java Island. The analysis based on 465 bp fragment of the cytochrome c oxidase 1 gene from 140 individuals. Analysis of overall populations proved that $H$. nemurus had a high gene diversity $(\mathrm{h}=0.935 \pm 0.016)$ and nucleotide diversity $(\pi=0.073 \pm 0.036)$. Within population analysis also showed that $H$. nemurus populations showed high levels of gene diversity $(h=0.338 \pm 0.128$ to $1.000 \pm 0.022)$ and nucleotide diversity $(\pi=0.001 \pm 0.001$ to $0.071 \pm 0.038)$. Those diversity values indicated that $\mathrm{H}$. nemurus had high level of genetic diversity, except for the Citanduy population. Population comparison showed that significant genetic differences observed among populations ( $p=0.000$ for both variance component and Fstvalue). However, pairwise comparison analysis indicated complex pattern of population differentiation. The high genetic diversity and complex pattern of population differentiation have important implication for H. nemurus conservation in Java Island.
\end{abstract}

Keywords: Genetic diversity, green catfish, Hemibagrus nemurus, Java, polymorphism

\section{INTRODUCTION}

Hemibagrus nemurus, known as green catfish or baung in the Indonesian Language, is among the popular freshwater species with high economic value. This bagrid species inhabits rivers, lakes, and reservoirs in Sumatra, Java, and Borneo (Muflikhah and Asyari 2007). It is among the popular raw materials for delicious cuisine serves either in traditional food stalls or big restaurants in Java. Nevertheless, in the present day, the restaurant's menu made from green catfish hardly found in the restaurants and food stalls, especially in Central and West Java (personal observations). The condition could indicate H. nemurus has already rarely found in nature due to overexploitation. The indication warned for more than ten years ago by Putro (2003) by providing data that natural catchment of green catfish in Klawing River Central Java decreased from 8.5 tons in 1998 to 5.35 tons in 2002. The Exploitation of $H$. nemurus is also possible to occur in most of the rivers across Java Island since high exploitation is a common feature in such area with dense communities.

In spite of the progressive decline of natural populations of $H$. nemurus across Java Island, there was limited data available on the genetic diversity and population variation of the river's population of green catfish in those areas. These data are essential for any conservation program; mainly, it is crucial in determining the choice of genetic units for conservation purposes and also for defining the source population for restoration program (Raeymaekers et al. 2009)

The previous report proved that overexploitation caused species declines, endangerment, and extinction (Hauser et al. 2002; Frankham 2003). The natural population decline caused by human exploitation might lead to lower genetic diversity (Harris et al. 2002; Hutchinson et al. 2003; Allendorf et al. 2008). It had reported that $H$. nemurus populations in Klawing and Serayu Rivers have a low genetic diversity as observed in their allozyme markers (Nuryanto and Setyaningrum 2008). A complex pattern of genetic diversity and population variations were reported in $H$. nemurus populations as assessed by RFLP markers of D-loop regions (Nugroho et al. 2003; 2005). In one hand, low genetic diversity was also observed in $H$. nemurus from Java and Sumatera as observed by RFLP markers of D-loop region (Nugroho et al. 2003). On the other hand, moderate-high genetic diversity was observed in four dam populations of $H$. nemurus in Java (Nugroho et al. 2005). Similar phenomena were observed in population variation analysis. Significant genetic differentiation was reported by Nugroho et al. (2005) among four reservoir's H. nemurus in Java Island, whereas no significant genetic differentiation was also reported between $H$. nemurus populations from Jatiluhur and Wonogiri (Nugroho et al. 2003).

The studies from Nuryanto and Setyaningrum (2008) and Nugroho et al. (2003, 2005) had a narrow scope in term of geographical and ecosystem type coverage, while Dodson et al. (1995) only collected samples from Cirata Reservoir in West Java. Therefore, all those studies did not 
provide a comprehensive picture of genetic diversity and population variation of $H$. nemurus across Java Island. Here, we reported genetic diversity and population variation in $H$. nemurus with broader geographical and ecosystem type coverage across Java Island using cytochrome c oxidase (COI) gene.

Numerous publications proved that partial sequence of cytochrome c oxidase I (COI) gene is a powerful and suitable molecular character for population genetic study (Luttikhuizen et al. 2003 Shefer et al. 2004; Barber et al. 2006; Kochzius and Nuryanto 2008; Nuryanto and Kochzius 2009; Diaz-Ferguson et al. 2010; Dorn et al. 2011; Sabando et al. 2011; Dung et al. 2013; Song et al. 2013; Zhang et al. 2014). It is due to that the nucleotide sequences of the COI gene have a high divergence within species because of its high mutation rate (Hebert et al. 2003). This study aims to investigate the genetic diversity and population variation of the green catfish $H$. nemurus populations among rivers across Java Island to provide data as a basis for defining genetic conservation unit and populations sources. The result of this study can be used as scientific references for setting genetic conservation units and choosing the source population for the restoration program.

\section{MATERIALS AND METHODS}

\section{Study area and sampling}

Hemibagrus nemurus samples collected from eleven different river systems; i.e., Cisadane (Csn), Ciliwung (Clw), Citarum (Ctm), Cimanuk (Cmk), Citanduy (Cty), Serayu (Sry), Klawing (Klw), Comal (Cml), Progo (Pgo), Bengawan Solo (Bso), and Brantas (Bnt) Rivers (Figure 1). Fish samples from Citarum and Bengawan Solo were collected from Cirata Reservoirs and Gajahmungkur Reservoirs. The populations represented lotic (river) and lentic (reservoir) ecosystems. Small piece of caudal fin clips was cut off from each fish for DNA examination. Fin clip samples were preserved in $96 \%$ of ethanol and stored at room temperature.

\section{Procedures}

\section{DNA extraction and genetic marker amplification}

Total genomic DNA isolated with the GeneJET ${ }^{\mathrm{TM}}$ Genomic DNA Purification Kit (ThermoFisher Scientific, Waltham, Massachusetts, United States; www.thermofisher.com), following the protocol of the manufacturer. The molecular marker used in this study was the mitochondrial COI gene. A fragment of this gene was amplified using a pair of universal primers fwd_seq: TCAACCAACCACAAAGACATTGGCAC, and rev_seq: TAGACTTCTGGGTGGCCAAA AATCA (Ward et al. 2005). The PCR was carried out in a total volume of $50 \mu \mathrm{L}$. The PCR reactions contained $1 \mu \mathrm{L}$ DNA template, $10 \mathrm{~mm}$ Tris- $\mathrm{HCl}(\mathrm{pH} 9), 50 \mathrm{~mm} \mathrm{KCl}, 2 \mathrm{~mm}$ of $\mathrm{MgCl} 2,0.2 \mu \mathrm{m}$ of each primer, $0.2 \mathrm{~mm}$ of each $\mathrm{dNTP}$ and $1 \mathrm{U}$ Taq polymerase. The following temperature profile used for the PCR: $94^{\circ} \mathrm{C}$ for $3 \mathrm{~min}$, followed by 35 cycles of $1 \mathrm{~min}$ at 94 ${ }^{\circ} \mathrm{C}, 1.5 \mathrm{~min}$ at $43{ }^{\circ} \mathrm{C}$, and $1 \mathrm{~min}$ at $72{ }^{\circ} \mathrm{C}$. The final extension conducted at $72{ }^{\circ} \mathrm{C}$ for $5 \mathrm{~min}$.

\section{DNA Sequencing and sequence editing}

The PCR products shipped to $1^{\text {st } B A S E}$ (www.baseasia.com) for sequencing. All sequences were edited with the program Bioedit (version 7.0.4.1; Hall 2005) and double-checked manually by eye to avoid mistakes. The sequences were translated to amino acids with the program ORF finder (www.cebl.auckland.ac.nz/index.php) and recheck by BLASTing the sequence to GenBank to exclude errors in sequencing and to verify if a functional mitochondrial DNA sequence was obtained and not a nuclear pseudogene. The first codon starts at nucleotide number one. A multiple sequences alignment obtained of 140 sequences by using clustalW (Thompson et al. 1994) as implemented in the software Bioedit (version 7.0.4.1; Hall 2005).

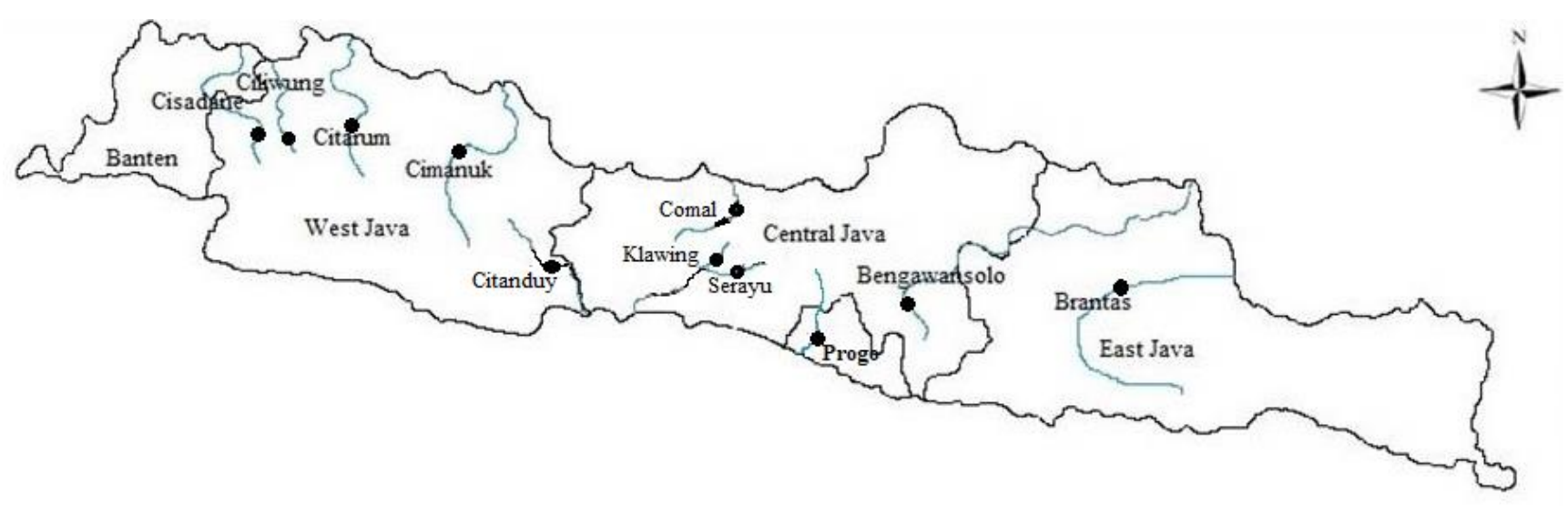

Figure 1. Maps of Java Island showing several rivers and the sampling sites of Hemibagrus nemurus (modified from Google maps) 


\section{Data analysis}

Genetic diversity

Haplotype diversity $h$ (Nei 1987) and nucleotide diversity $\pi$ (Nei and Jin 1989) were calculated in Arlequin software version 3.5 (Excoffier and Lischer 2010). The calculation based on the Kimura 2-parameter substitution model.

\section{Genetic variation among populations}

Significance of genetic variation among populations was tested using analysis of molecular variance (AMOVA) and pairwise $F_{\mathrm{ST}}$-values. Both statistical calculations were carried out using the software Arlequin version 3.5 (Excoffier and Lischer 2010). The Kimura 2-parameter (K2P) substitution model was used during the calculation.

\section{RESULTS AND DISCUSSION}

\section{DNA polymorphism and genetic diversity}

Sequences alignment of the COI gene obtained of 465 bp length fragments from $140 \mathrm{H}$. nemurus individuals collected in eleven rivers across the Java Island Indonesia (Table 1). Among these 140 individuals, a total number of 85 haplotypes were observed, with 218 polymorphic sites or loci $(33.798 \%)$ out of 645 loci. It is mean that the percentage of the most common or dominant loci was only $66.202 \%$. The resulted polymorphisms value proved that the COI gene of green catfish $H$. nemurus was highly polymorphic. According to Hartl and Jones (2009), a gene referred as to polymorphic if the most common allele or site has a frequency of less than $95 \%$.

High polymorphism in the COI gene of green catfish, as observed in this study is due to COI gene has a high mutation rate. It has been proven by Hebert et al. (2003) that $\mathrm{COI}$ gene has higher mutation rate compared with two other mitochondrial genes; such as $12 \mathrm{~S}$ and $16 \mathrm{~S}$ genes which are also commonly used in population genetic study. High level of genetic polymorphism in the COI gene was also reported from various species (Nuryanto et al. 2018; Nuryanto et al. 2017; Barber et al. 2006).

Table 1. Sample sites, number of sequences $(n)$, number of haplotypes (nhp), haplotype diversity $(h)$, nucleotide diversity $(\pi)$ for $H$. nemurus across Java Island

\begin{tabular}{lccccc}
\hline \multirow{2}{*}{ Sample site } & \multirow{2}{*}{ Code } & \multirow{2}{*}{ n } & \multirow{2}{*}{ nhp } & \multicolumn{2}{c}{ Genetic diversity } \\
\cline { 5 - 6 } & & & & $\mathbf{h}$ & $\boldsymbol{\pi}$ \\
\hline Overall & - & $\mathbf{1 4 0}$ & $\mathbf{8 5}$ & $\mathbf{0 . 9 3 5} \pm \mathbf{0 . 0 1 6}$ & $\mathbf{0 . 0 7 3} \pm \mathbf{0 . 0 3 6}$ \\
Samples & & & & & \\
Brantas & Bnt & 8 & 8 & $1.000 \pm 0.063$ & $0.006 \pm 0.004$ \\
Cimanan Solo & Bso & 16 & 16 & $1.000 \pm 0.022$ & $0.021 \pm 0.011$ \\
Cisadane & Cmk & 6 & 6 & $1.000 \pm 0.096$ & $0.018 \pm 0.011$ \\
Klawing & Csn & 10 & 4 & $0.533 \pm 0.180$ & $0.071 \pm 0.038$ \\
Ciliwung & Klw & 8 & 8 & $1.000 \pm 0.063$ & $0.069 \pm 0.038$ \\
Citanduy & Clw & 13 & 6 & $0.795 \pm 0.085$ & $0.003 \pm 0.002$ \\
Citarum & Cty & 22 & 5 & $0.338 \pm 0.128$ & $0.001 \pm 0.001$ \\
Comal & Cml & 16 & 9 & $0.901 \pm 0.062$ & $0.006 \pm 0.004$ \\
Serayu & Sry & 14 & 6 & $0.692 \pm 0.124$ & $0.002 \pm 0.001$ \\
Progo & Pgo & 13 & 10 & $0.949 \pm 0.051$ & $0.050 \pm 0.026$ \\
\hline
\end{tabular}

Note: ${ }^{*} 0.05 \geq P \geq 0.01 ;{ }^{* *} 0.01>P \geq 0.001 ; * * * P<0.001 ; \mathrm{NS}$, not significant
Polymorphisms level of the COI gene of green catfish in this study indicates that the used fragment is variable enough to be used in genetic diversity analysis of $H$. nemurus populations across Java Island. Overall, haplotype diversity $(h)$ was of $0.935 \pm 0.016$, and nucleotide diversity $(\pi)$ was of $0.073 \pm 0.036$ (Table 2 ). Both genetic diversity values proved that generally, the green catfish populations in Java Island have high genetic diversity. The obtained level of genetic diversity in present study comparable to that level in Nothobranchius fish (Dorn et al. 2011), Channa striata (Song et al. 2013), Nodularia douglasiae Bivalvia (Liu et al. 2017), Trochid gastropod (DiazFerguson et al. 2010), tea Geometrid Ectropis obliqua (Zhang et al. 2014), two species of river's insects (Sabando et al. 2011), Haplorchis taichui (Dung et al. 2013). The present study and previous studies showed that the COI gene is a highly variable genetic marker in a wide range of animal phyla and proved that the COI gene is a suitable marker for population genetic studies.

High level of genetic diversity was also reported in $H$. nemurus populations from four different areas across Thailand (Leesa-Nga et al. 2005). A similar result also published on four reservoir's populations of H. nemurus in Java Island (Nugroho et al. 2005). However, the comparison to Leesa-Nga et al. (2005) and Nugroho et al. (2005) studies was not completely congruence because they used a different genetic marker to what we used in the present study. Here we used the COI gene as a genetic marker, while Leesa-Nga et al. (2005) used RAPD fingerprint and Nugroho et al. (2005) used d-loop PCR-RFLP markers. Nevertheless, here we provided more reliable and comprehensive genetic diversity data compared to Nugroho et al. (2005) since we used more variable and much more sampling sites across Java Island and represented more variable ecosystem types from lotic (rivers) and lentic (reservoirs) habitats while Nugroho et al. (2005) only collected samples from four lentic habitats (reservoirs).

Overall genetic diversity value of the COI gene of green catfish resulted in our study was higher compared to that value reported in Tor tambroides fish (Esa et al. 2008), mussel Epioblasma torulosa rangiana (Zanatta and Murphy 2007) and in Bactericera cockerelii (Liu et al 2006). The genetic diversity patterns in the present study and the studies from Esa et al. (2008), Zanatta and Murphy (2007) and Liu et al. (2006) indicate that genetic diversity of the COI gene showed a complex pattern of genetic diversity level across phyla. Complex pattern of genetic variation even might be observed within species that are collected from several local populations, such as observed in Capoeta trutta fish (Parmaksiz and Eksi 2017) and Macarorchestia remyi (Pavesi et al. 2011) and other studies in various animals (Sugama et al. 2002; Baber et al. 2002, 2006; Luthikuizen et al. 2003; Kochzius et al. 2009).

The present study was also showed higher genetic diversity of $H$. nemurus population to that observed by Nuryanto and Setyaningrum (2008). However, the comparison was not congruence since Nuryanto and Setyaningrum (2008) used a different genetic marker. Nuryanto and Setyaningrum (2008) used allozyme markers which are well known as a stable marker that is less 
variable compared to the COI gene that we used in the present study which is famously known as highly variable molecular marker. A not parallel comparison has also resulted when we compare present study to earlier studies although all the earlier studies also proved a complex pattern of genetic diversity. For example, a complex pattern of genetic diversity was observed in other bagrid species Horabagrus brachysoma from three different locations in the Western Ghats region, Kerala, India (Muneer et al. 2009). Similar results were reported to occur in Aorichthys seenghala (Garg et al. 2009), Arapaima gigas (Hrbek et al. 2005) and in Clarias batrachus (Garg et al. 2010). But again, since all of the previous studies used different markers with our present study, the comparison does not mean congruent.

Analysis within-population indicated that variable genetic diversity values were variable depending on the population. Haplotype diversity within population ranges from $0.338 \pm 0.128$ in the population from Citanduy River to 1.000 in Bengawan Solo, Brantas, Cimanuk, and Klawing Rivers. Nucleotide diversity ranges from 0.001 in Citanduy population to 0.071 in Cisadane population (Table 1). Those genetic values proved that the genetic diversity of the green catfish $\mathrm{H}$. nemurus in Java Island ranged from low to high genetic diversity. Low-level genetic diversity on $H$. nemurus Citanduy River could be due to overexploitation. This argument was proposed based on a fact that during sample collection, we found that fishers at Citanduy River use electric shocker to catch the fish. Electric fishing was also a common phenomenon in Brantas River, but Brantas River is far broader than Citanduy River. According to Nuryanto et al. (2012) proved that the broader and bigger river has more and variable microhabitat. The wider river has more variable riverscape for a specific allele to adapt. Therefore, the impact of electric fishing was not yet visible in the Brantas River compared to Cintanduy River. It has been known that there were significant correlation genetic diversity and variable riverscape (Davis et al. 2017; Brauer et al. 2016; Cooke et al. 2014; Cook et al. 2011; Olsen et al. 2010).

Electric fishing kills individuals from all life stages from eggs up to mature individuals and lead to mass mortalities even not targeted size, which might speed up the reduction of the population size of green catfish population in Citanduy River. A small population might lead to inbreeding depression. A continuous effect of inbreeding depression would decrease genetic diversity. Reduction of genetic diversity on small population might be caused by increasing of inbreeding probability with the potential of inbreeding depression (Hartl and Jones 2009). Population decline due to overexploitation may cause a loss of genetic diversity (Allendorf et al. 2008).

Moreover, overexploitation is suggested to affect population size and produce a genetic effect that contributes to extinction risk (Frankham 2003). The role of genetic factors on conservation includes the impact of genetic drift and inbreeding depression. Genetic drift has caused long term of losing genetic diversity magnitude on overexploited populations (Hauser et al. 2002).

The ten remaining populations in our present study had a high haplotype diversity of the COI gene. Great haplotype diversity within populations of the COI was also reported in numerous animal phyla spanning from an arthropod (Barber et al. 2002), Gastropod and Linckia laevigata (Kochzius et al. 2009) up to fish (Hrbek et al. 2005). High genetic diversity of $H$. nemurus was also observed in the population from Java, Sumatera, and Kalimantan (Dodson et al. 1995). However, the comparison to Dodson et al. (1995) was not balanced since they used PRC-RFLP marker of mitochondrial DNA and was only collected sample from a single location in Java Island. Therefore, their sample size cannot be used as a reference in the conservation of green catfish in Java Island.

To ensure that the pattern of population genetic of $H$. nemurus obtained in the present study describe a general pattern for that species, further study using other markers such as microsatellite and D-loop regions would be very interesting. There is a general acceptance that microsatellite and D-loop are a highly polymorphic marker and suitable marker for a population study. However, the choice of both markers for population study in freshwater fish should be done with carefulness since several studies also proved both markers also showed a complex pattern of genetic diversity and population variation in various animals, including freshwater fish.

Previous studies proved that more than 14 freshwater fish species has low genetic diversity in their microsatellite loci (Cheng et al. 2017; Esa and Rahim 2013; Meldgaard et al. 2003; Esa et al. 2011; Nguyen et al. 2008; Mohindra et al. 2004; Costello et al. 2003; DeWoody and Avise 2000). Complex pattern of microsatellite markers were also reported in fish with gene diversity range from very low to very high depend on the locus (Abbas et al. 2017; Achrem et al. 2017; Gouskov et al. 2016; Jungker et al. 2011; Wang et al. 2007; Castric et al. 2002; Hauser et al. 2002; Castric et al. 2001). Low genetic diversity of certain microsatellite loci in river Sculpin Cottus gobio was observed although the utilized loci were considered to be highly polymorphic in an earlier study (Hanfling and Weetman 2006). Even in freshwater Bivalvia, it has been proven that the COI gene sequences of Nodularia douglasiae (Bivalvia) were highly more diverse than that in microsatellite marker (Liu et al. 2017) and low diversity of microsatellite markers was also reported in Crassostrea ariakensis (Bivalvia) which is comparable to the value obtained from PCR-RFLP COI and COIII (Zhang et al. (2005).

A complex pattern of genetic diversity was also reported when analyzed using D-loop markers. Low to medium genetic diversity pattern on RFLP D-loop control region was observed in two species of catfish with the haplotype diversity range from 0.295 up to 0.674 (So et al. 2006). A similar pattern of genetic diversity $(h=0.00$ to 0.80) was also observed in giant tortoises when observed using the control region or D-loop marker (Beheregaray et al. 2003). Medium-high genetic diversity of RFLP D-loop marker was observed in bigeye tuna, Thunnus obesus (Chow et al. 2000). The remaining studies showed high genetic diversity in various animal phyla based on D-loop control region markers (Zhong et al. 2013; Santos et al. 2007; Chiang et al. 2006; Aboim et al. 2005). 
Table 2. Analysis of molecular variances among H. nemurus populations

\begin{tabular}{lcccc}
\hline $\begin{array}{l}\text { Source of } \\
\text { variation }\end{array}$ & d.f & $\begin{array}{c}\text { Sum of } \\
\text { squares }\end{array}$ & $\begin{array}{c}\text { Variance } \\
\text { components }\end{array}$ & $\begin{array}{c}\text { Percentage } \\
\text { of variation }\end{array}$ \\
\hline $\begin{array}{l}\text { Among } \\
\text { populations }\end{array}$ & 10 & 17.541 & $0.109 \mathrm{Va}$ & 22.62 \\
$\begin{array}{l}\text { Within- } \\
\text { population }\end{array}$ & 129 & 48.380 & $0.375 \mathrm{Vb}$ & 77.38 \\
$\begin{array}{l}\text { Total } \\
\begin{array}{l}\text { Fixation } \\
\text { Index (FST) }\end{array}\end{array}$ & 0.226 & $\begin{array}{l}65.921 \\
\text { Remark: } \mathrm{Va} \text { and FT P- } \\
\text { value }=0.000 \pm 0.000\end{array}$ \\
\hline
\end{tabular}

\section{Genetic differentiation among populations}

Genetic differentiation among the population can be inferred from variance component (Va) and average fixation index $\left(\mathrm{F}_{\mathrm{ST}}\right)$ values on AMOVA result. The result shows that the populations of $H$. nemurus in Java Island have Va value of 0.109 and $\mathrm{F}_{\mathrm{ST}}$ value of 0.226 with the probability value (p-value) was of 0.000 (Table 2).

The observed $p$-value of $0.000 \pm 0.000$ for both $\mathrm{Va}$ and average FST values indicated that significant genetic variation occurred among $H$. nemurus populations across Java Island. Significant genetic differences among rivers on this study were expected because such pattern, theoretically, is a typical case since rivers are fundamentally fragmented ecosystem and considered as 'closed' ecosystem. Even in the same island, such as in Java Island, the connectivity among river ecosystems is also inhibited by a physical barrier as distribution barrier. There was a general acceptance that rivers are separated or closed ecosystems. Therefore, freshwater species tend to exhibit higher levels of genetic structuring than those inhabiting estuarine or marine environments (Hughes et al 2009). Significant population variation can be observed even among tributaries within a river system without the presence of physical barrier (Kano et al. 2011). Restricted dispersal results in low levels of gene flow among rivers and creates fragmented populations such as in H. nemurus population in Java Island, as shown in the present study. According to Unmack (2001), the distribution or movement of freshwater species between drainages depends on the connectivity of these freshwater systems. Genetic differentiation among rivers is also affected by the magnitude of social pressure among waterways. It had reported that anthropogeny activities improve source-sink population differentiation in the river population of Cottus gobio (Hanfling and Weetman 2006).

Significant variation in the COI gene among populations was also observed in Channa striata (Song et al. 2013), lanternfishes (Pappalardo et al. 2015), Oephronemus goramy (Nuryanto et al. 2018), Tor tambroides (Esa et al. 2008), Haplorchis taichui (Dung et al. 2013), Macarorchestia remyi (Pavesi et al. 2011), and in Amblema plicata (Elderkin et al. 2007). The significant population variation that resulted in the present study and previous studies proved that the COI gene is a reliable marker for population genetic differentiation in a broad range of animals. However, no significant genetic variation was observed in other fish

More detail information on the genetic variation among pair-populations obtained from a significant $p$-value of pairwise $\boldsymbol{\Phi}_{\text {st }}$ comparison is summarized in Table 3. It seems that the complex pattern of genetic variation among populations has occurred. This phenomenon is very complicated to explain. A similar pattern of complex genetic differentiation among river populations had reported in numerous studies using various marker and species (Kamarudin and Esa 2009). Specific in H. nemurus, previous studies from Nugroho et al. (2003) showed significant genetic differences among the reservoir's populations in Java Island. In another study, Nugroho et al. (2005) stated that $H$. nemurus populations from Jatiluhur and Wonogiri reservoirs had less genetic distance compared to the population from Jambi (Sumatera Island).

Further studies based on mtDNA RFLP and morphological divergences Dodson et al. (1995) divided South-east Asian H.nemurus populations into three different regional groups, i.e., Indochina, Sundaic, and Sarawak groups with the haplotype mean differentiation of 2.22. Similarly, the high genetic structure was also revealed on two other riverine species $H$. guttatus populations (Yang and $\mathrm{He}$ 2008) and H. macropterus (Yang et al. 2009). Nevertheless, all those previous studies were used a different marker to our research. Hence, the comparison is not congruent. Our present study enriches, comprehended, and updating the available data on genetic differentiation in river population. However, some other publication on different organisms and ecosystem using COI gene showed strong genetic structure among populations (Barber et al. 2002, 2006; Kochzius and Nuryanto 2008; Nuryanto and Kochzius 2009; Kochzius et al. 2009).

Table 3. Matrix of significant $\Phi_{\text {st }} p$-values (significance Level=0.0500)

\begin{tabular}{|c|c|c|c|c|c|c|c|c|c|c|c|}
\hline $\begin{array}{l}\text { sample } \\
\text { site }\end{array}$ & Bnt & Bso & Cmk & Csn & Klw & Clw & Cty & Ctm & $\mathrm{Cml}$ & Sry & Pgo \\
\hline Bnt & & - & - & + & - & + & + & + & + & + & \\
\hline Bso & - & & - & + & - & + & + & + & + & + & \\
\hline $\mathrm{Cmk}$ & - & - & & + & - & + & + & - & + & + & \\
\hline Csn & + & + & + & & + & + & + & + & + & + & \\
\hline Klw & - & - & - & + & & + & + & + & + & + & \\
\hline Clw & + & + & + & + & + & & + & + & + & + & \\
\hline Cty & + & + & + & + & + & + & & + & + & - & \\
\hline $\mathrm{Ctm}$ & + & + & - & + & + & + & + & & + & + & \\
\hline $\mathrm{Cml}$ & + & + & + & + & + & + & + & + & & + & \\
\hline Sry & + & + & + & + & + & + & - & + & + & & \\
\hline Pgo & - & + & - & + & - & + & + & + & - & + & \\
\hline
\end{tabular}


A complex pattern of population variation was also observed in various animal populations, even when it is analyzed using genetic markers that accepted as highly polymorphic markers, such as D-loop and microsatellite markers. In one hand, no significant population variation was reported in several fish species though high genetic diversity within populations was observed, such as in Bluefin tuna (Ely et al. 2002); freshwater fish Colossoma macropomum (Santos et al. 2007) and in wild populations in Laporinus elongatus (Martins et al. 2003). No significant genetic structure was also reported even in distantly separated bigeye tuna (Thunnus obesus) based on D-loop control region (Chiang et al. 2006). A similar result was reported in Pan paniscus (Hominidae) (Erikson et al. 2004). In the second hand, significant genetic structure was observed in earlier studies when analyzed using D-loop control region (Zhong et al. 2013), even among populations with a low level of genetic diversity within population, a significant population variation was reported (So et al. 2006; Davey et al. 2003; Fauvelot et al. 2003).

Similar phenomena were observed when the microsatellite marker is utilized in a population study. Moderate to significant population variation was observed in several fish species, such as in Channa argus (Yan et al. 2017), Misgurnus anguillicaudatus (Abbas et al. 2017), Tor tambroides (Esa and Rahim 2013), two species of notothenioid fish (Damerau et al. 2012), Nothobranchius furzeri (Bartakova et al. 2013), Labeo dero (Chaturvedi et al. 2011), littoral fish Tripterygion delaisi (CarrerasCarbonell et al. 2007), Cottus gobio (Junker et al. 2012), and in gorilla (Bergl and Vigilant 2007). However, numerous studies also proved no significant microsatellite variation among fish population, such as in fish Wallago attu populations (Basharat et al. 2016), Tor duoronensis (Esa et al. 2011), five species of notothenioid fish (Damerau et al. 2012), two coral reef fish (Purchel et al. 2006), among most populations of Theragra chalcogramma (O'reilly et al. 2004), and among some populations of Pagellus bogaraveo (Stockley et al. 2005). Indeed, a study in freshwater mussel Cumberlandia monodonta results in a similar pattern of population variations from the COI gene and microsatellite data (Inoue et al. 2014).

Based on the result of the present study and all previous studies; the COI sequences, RFLP, D-loop sequences and microsatellite markers did not show an absolute level of genetic variability and population variation. The variability levels and significance of population variation based on those three different markers depend on the species or even local population of certain species. The best thing would be to use more than one genetic marker to obtain a general pattern of population genetic of certain species. However, if one maker can answer the hypothesis, the utilization of that marker would be sufficient.

\section{Genetic conservation unit and restoration scheme}

Hemibagrus nemurus populations in Java Island have a high genetic diversity level, except the Citanduy River. High genetic diversity of the COI gene as observed in this study proved that the $H$. nemurus populations across Java Island are stable. However, for conservation purpose, recent data on catchment is needed to obtain an overview or estimate of the current population size in each river. For Citanduy River with low genetic diversity, it could indicate population bottleneck after over-harvesting in the past periods. It has reported that over-harvesting cause low genetic diversity of a certain population (Kochzius and Nuryanto, 2008). Low genetic diversity in Citanduy River might be caused by founder effect due to re-colonization of the river after hot lava from Galunggung mountain eruption in 1982 (Ariwibowo 2017) dismissed habitat lost in Citanduy River. According to Kochzius and Nuryanto (2008) re-colonization of small founder population might lead to low genetic diversity. However, mismatch distribution analysis could not be performed to check bottleneck event in Citanduy River. Therefore, to support the argument of bottleneck event in that river, a serial catchment data is also vital to get a more factual picture about the present condition of $H$. nemurus population in Citanduy River.

Mismatch distribution analysis could not be conducted in several other populations; i.e., Bengawan Solo, Cisadane, Klawing, Ciliwung, and Serayu. Nevertheless, these five populations showed medium (Cisadane, Ciliwung, and Serayu) to high (Bengawan Solo and Klawing) genetic diversity. Mismatch distribution analysis for overall samples indicated that the river populations of $H$. nemurus in Java Island indicated several bottleneck events (blue line Figure 2). Population declines of $H$. nemurus in Java Island also indicated by simulated and model frequency lines (Figure 2). However, some populations had high genetic diversity. This high genetic diversity might indicate population expansion population growth after population decline. It is shown by not significant sum of square deviation (SSD) and Harpending's Regardless index (HRI) values ( $p$-value > 0.05) (Roger and Harpending 1992; Rogers 1995).

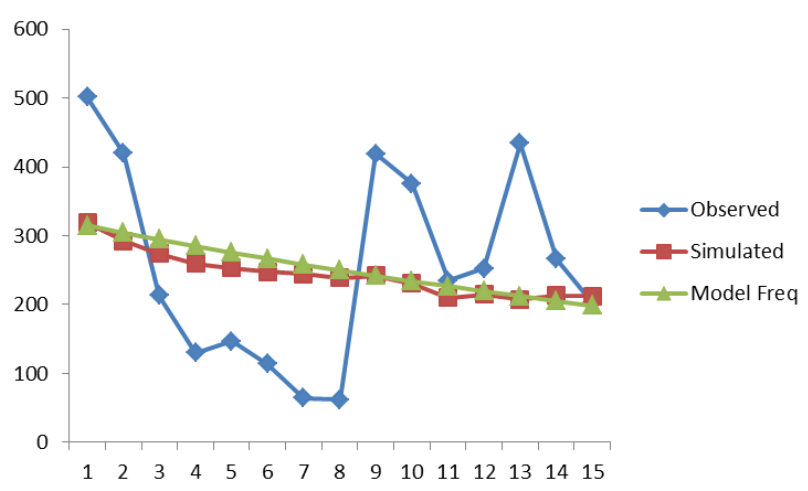

Figure 2. Mismatch distribution analysis indicate several bottleneck events in the river populations of H. nemurus in Java Island 
Table 4. Sampling site grouping based on significance pairwise $\Phi_{\text {st } p \text {-values and geographic position }}$

\begin{tabular}{ll}
\hline Group & River \\
\hline I & Brantas and Bengawan Solo \\
II & Citanduy and Serayu \\
III & Citarum-Cimanuk \\
IV & Comal-Progo \\
V & Cisadane \\
VI & Ciliwung \\
VII & Klawing \\
\hline
\end{tabular}

A careful examination of the comparison significance values as presented in Table 3 and considering the geographic position of the sampling sites (rivers) resulting in a logic grouping instead. This grouping is expected to use as a scientific basis for defining genetic conservation units and source populations for the restoration program. The rivers grouping presented in Table 4 and illustrated in Figure 3.

As shown in Table 4 that sampling sites divided into seven genetic groups. The first group consisted of Brantas and Bengawan Solo Rivers and considered as a single genetic conservation unit. It is mean that both populations could be genetically managed together. It was because the green catfish populations from both rivers were genetically not different, and both rivers are geographically nearby and also empties in the Java Sea in the North of East Java. In case of the restoration program, Bengawan Solo population referred to as a source population because it has higher nucleotide diversity than Brantas population. Citanduy and Serayu Rivers placed together in a single genetic unit separated from other populations because both populations are a genetically similar one to another, while they are genetically different from the remaining populations. Within this group 2, Serayu suggested as a source population for restoration program since it has higher genetic diversity than that Cintanduy River. The third group formed by Citarum and Cimanuk Rivers, these two rivers could also be managed as a single genetic conservation unit because genetically not different. Both populations could be referred to as to source population for them because the two populations have high genetic diversity. Comal and Progo Rivers placed in group number 4 and it can be managed as a single genetic conservation unit. Klawing Rivers, though were genetically similar to specific other populations, it could not be managed together as a single unit with its genetically similar populations because of technical difficulties due to their geographic location. Therefore, Klawing River stands alone as a single genetic conservation unit. However, it can be used as a source population for other genetically similar population such as for Brantas, Bengawan Solo, and Cimanuk due to its high genetic diversity. Different to other population which showed genetic similarity to specific populations, Cisadane, and Ciliwung populations were different to all green catfish populations under study. Therefore, each population should be managed separately as a single conservation genetic unit. Schematic diagram of the proposed genetic conservation units is presented in Figure 2. According to Kochzius and Nuryanto (2008) and Nuryanto and Kochzius (2009), genetically similar populations can be managed together as a single conservation unit. Nevertheless, river grouping for useful application of conservation management should also consider the ecology of each river and other genetic data from other markers, such as D-loop sequences and microsatellite.

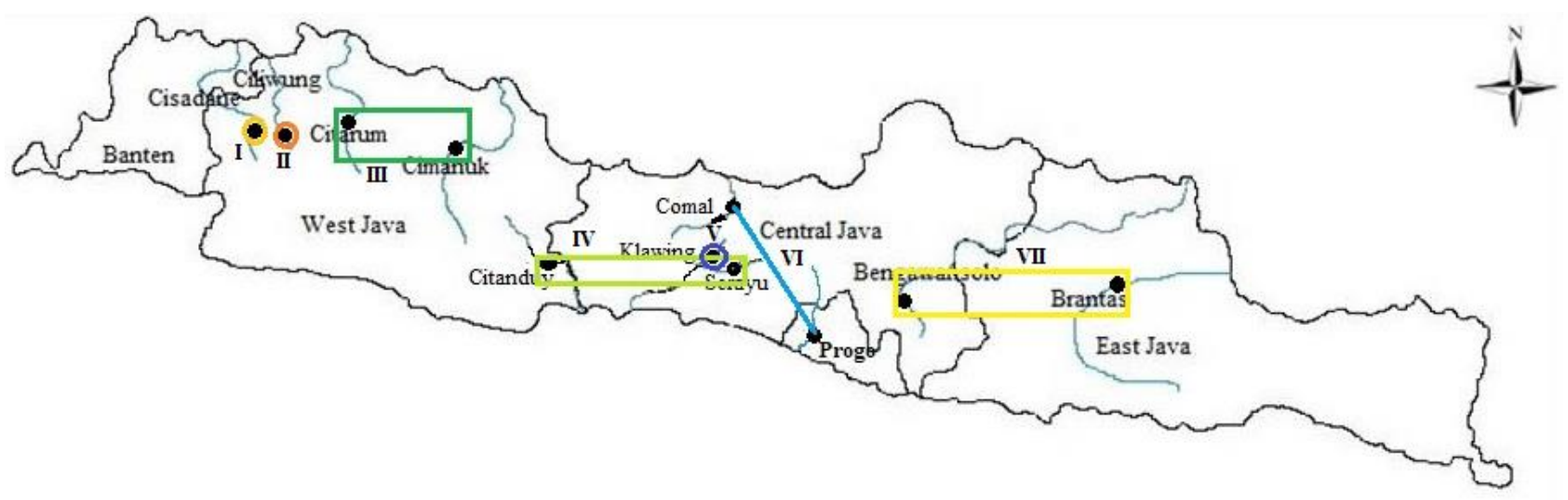

Map data @2018 Google $100 \mathrm{~km} \longleftarrow$

Figure 3. Map of Java Island showing a proposed seven genetic conservation units of Hemibagrus nemurus (I-VII) 
Klawing River was unique. In one hand, it was different from Surayu River though it empties in Serayu River. In the second hand, it was genetically similar to Progo River while they are geographically distantly separated. This phenomenon explained in two ways. Firstly, genetic differences between Klawing and Serayu Rivers populations could be due to the nature of $H$. nemurus as potamodromous species with limited migration activities. They are only moving to other parts of the river with high vegetation to spawn (Froese and Pauly 2019). It assumed that there was little possibility for $H$. nemurus to move to other streams, while fish samples collected at the upper of meeting point between Klawing and Serayu River.

In some cases, genetic differentiation among river populations does not necessarily need a physical barrier. Kano et al. (2011) had proven that Salvelinus fontinalis shows significant genetic differentiation among populations in the absence of physical barrier within the tributary. Secondly, genetic similarity between Klawing and Progo while they are geographically separated populations could be due to convergent evolution between both populations caused by similar environmental conditions. However, this argument needs additional ecological data from both rivers (Klawing and Progo). According to Stern (2013), convergent evolution in genetic level molecular results in the same characteristic two different lineages. Convergent evolution was also reported to occur in cichlid fishes (Muschick et al. 2012).

The populations of green catfish $H$. nemurus in Java Island have high genetic diversity, except the population in Citanduy River. This fish also showed a complex pattern of genetic differentiation among the rivers and led the rivers separated into seven genetic conservation units. Both data have important implication for the conservation of $H$. nemurus in Java Island. In the case of the reintroduction program, population with high genetic diversity can be chosen as a source population to increase genetic diversity in the population with low genetic diversity by considering the pattern of genetic differentiation among rivers. However, to obtain a general picture on population genetic of $H$. nemurus populations in Java Island, the utilization of other genetic markers, such as D-loop and microsatellite markers should be considered.

\section{ACKNOWLEDGEMENTS}

We would like to thank Nagao Environment Foundation (NEF) Japan, which provided the funding to make this study was possible. Thank you very much also to Universitas Jenderal Soedirman (Unsoed) and Faculty of Biology of Unsoed for the facilities that we can utilize during the study. We also thank peoples for their help to the researcher in collecting fish samples and even some students such as Tofan, Sani, and Nanang who were become guides during the field trips. Finally, our high appreciation is delivered to reviewers for valuable suggestion and inputs to raise the scientific value of this manuscript.

\section{REFERENCES}

Abbas K, Xiaoyun Z, Weimin W. 2017. Microsatellite markers reveal genetic differentiation of Chinese dojo loach Misgurnus anguillicaudatus in the Yangtze River basin. Turk J Fish Aquat Sci 17: 1167-1177.

Aboim MA, Menezes M, Schlitt T, Rogers AD. 2005. Genetic structure and history of populations of the deep-sea fish Helicolenus dactylopterus (Delaroche, 1809) inferred from mtDNA sequence analysis. Mol Ecol 14: 1343-1354.

Achrem M, Skuza L, Kirczuk L, Domagala J, Pilecka-Rapacz M, Czerniawski R. 2017. Assessment of genetic variability in common whitefish from the catchment area of the Oder River using microsatellite markers. Act Biol 24: 5-13.

Allendorf FW, England PR, Luikart G, Ritchie PA, Ryman N. 2008. Genetic effects of harvest on wild animal populations. Trends Ecol Evol 23 (6): 327-337.

Ariwibowo GA. 2017. Disaster handling of Galunggung mountain eruption in 1982-1983. Patrawidya 18 (2): 173-188.

Barber PH, Palumbi SR, Erdmann MV, Moosa MK. 2002. Sharp genetic breaks among populations of Haptosquilla pulchella (Stomatopoda) indicate limits to larval transport: patterns, causes, and consequences. Mol Ecol 11: 659-674.

Barber PH, Erdmann MV, Palumbi SR. 2006. Comparative phylogeography of three codistributed stomatopods: origins and timing of regional lineage diversification in the coral triangle. Evolution 60: 1825-1839

Bartakova V, Reichard M, Janko K, Polacik M, Blazek R, Reichwald K, Cellerino A, Bryja J. 2013. Strong population genetic structuring in an annual fish, Nothobranchius furzeri, suggests multiple savannah refugia in southern Mozambique. BMC Evol Biol 13: 196. DOI: 10.1186/1471-2148-13-196

Basharat H, Gafhoor A, Chavhan A, Zafar MM, Abbas K, TabasumJ, Parveen R. 2016. Microsatellite markers revealed poor genetic structure of Wallago attu in Punjab, Pakistan. Intl J Life Sci 4 (3): 385-393.

Beheregaray LB, Ciofi C, Caccone A, Gibbs JP, Powell JR. 2003. Genetic divergence, phylogeography and conservation units of giant tortoises from Santa Cruz and Pinzon, Galapagos Islands. Conserv Genet 4: 31-46.

Bergl RA, Vigilant L. 2007. Genetic analysis reveals population structure and recent migration within the highly fragmented range of the Cross River gorilla (Gorilla gorilla diehli). Mol Ecol 16: 501-516.

Brauer CJ, Hammer MP, Beheregaray LB. 2016. Riverscape genomics of a threatened fish across a hydro climatically heterogeneous river basin. Mol Ecol 25: 5093-5113.

Carreras-Carbonell J, Macpherson E, Pascual M. 2007. High selfrecruitment levels in a Mediterranean littoral fish population revealed by microsatellite markers. Mar Biol 151: 719-727.

Castric V, Bonney F, Bernatchez L. 2001. Landscape structure and hierarchical genetic diversity in the brook charr, Salvelinus fontinalis. Evolution 55 (5): 1016-1028.

Castric V, Bernatches L, Belkhir K, Bonhomme F. 2002. Heterozygote deficiencies in small lacustrine populations of brook charr Salvelinus fontinalis Mitchill (Pisces, Salmonidae): a test of alternative hypotheses. Heredity 89: 27-35.

Chaturvedi A, Mohindra V, Singh RK, Lal KK, Punia P, Bhaskar R, Mandal A, Narain L, Lakra WS. 2011. Population genetic structure and phylogeography of cyprinid fish, Labeo dero (Hamilton, 1822) inferred from allozyme and microsatellite DNA marker analysis. Mol Biol Rep 38: 3513-3529.

Cheng F, Zhao S, Schmidt BV, Ye L, Hallerman EM, Xie S. 2017. Morphological but no genetic differentiation among fragmented populations of Hemiculter leucisculus (Actinopterygii, Cyprinidae) from a lake complex in the middle Yangtze, China. Hydrobiology. DOI: 10.1007/s10750-017-3464-0.

Chiang H-C, Hsu C-C, Lin H-D, Ma GC, Chiang T-Y, Yang H-Y. 2006. Population structure of bigeye tuna (Thunnus obesus) in the South China Sea, Philippine Sea and western Pacific Ocean inferred from mitochondrial DNA. Fish Res 79: 219-225.

Chow S, Okamoto H, Miyabe N, Hiramatsu K, Barut N. 2000. Genetic divergence between Atlantic and Indo-Pacific stocks of bigeye tuna (Thunnus obesus) and admixture around South Africa. Mol Ecol 9: 221-227. 
Cook BD, Kennard MJ, Real K, Pusey BJ, Hughes JM. 2011. Landscape genetic analysis of the tropical freshwater fish Mogurnda mogurnda (Eleotridae) in a monsoonal river basin: Importance of hydrographic factors and population history. Fresh Biol 56 (5): 812-827.

Cooke GM, Landguth EL, Beheregaray LB. 2014. Riverscape genetics identifies replicated ecological divergence across an Amazonian ecotone. Evolution 68 (7): 1947-1960.

Costello AB, Down TE, Pollard SM, Pacas CJ, Taylor EB. 2003. The influence of history and contemporary stream hydrology on the evolution of genetic diversity within species: An examination of microsatellite DNA variation in bull trout, Salvelinus confluentus (Pisces: Salmonidae). Evolution 57 (2): 328-344.

Damerau M, Matschiner M, Salzburger W, Hanel R. 2012. Comparative population genetics of seven notothenioid fish species reveals high levels of gene flow along ocean currents in the southern Scotia Arc, Antarctica. Polar Biol 35: 1073-1086.

Davey ML, O’Brien L, Ling N, Gleeson DM. 2003. Population genetic structure of the Canterbury mudfish (Neochanna burrowsius): Biogeography and conservation implications. N Z J Mar Freshw 37 (1): $13-21$.

Davis CD, Epps CW, Flitcroft RL, Banks MA. 2017. Refining and defining riverscape genetics: How rivers influence population genetic structure. WIRES Water 5 (2): e1269. DOI: $10.1002 /$ wat 2.1269

DeWoody JA, Avise JC. 2000. Microsatellite variation in marine, freshwater and anadromous fishes compared with other animals. J Fish Biol 56 (3): 461-473.

Diaz-Ferguson E, Haney R, Wares J, Silliman B. 2010. Population genetics of a Trochid Gastropod broadens picture of Caribbean Sea connectivity. PloS ONE 5 (9): e12675. DOI 10.1371/journal.pone.0012675.

Dodson JJ, Colombani F, Ng PKL. 1995. Phylogeographic structure in mitochondrial DNA of a South-east Asian freshwater fish, Hemibagrus nemurus (Siluroidei; Bagridae) and Pleistocene sea-level changes on the Sunda shelf. Mol Ecol 2: 331-346.

Dorn A, Ng'oma E, Janko K, Reichwald K, Polacik M, Platzer M, Cellerino A, Reichard M. 2011. Phylogeny, genetic variability and colour polymorphism of an emerging animal model: The short-lived annual Nothobranchius fishes from southern Mozambique. Mol Phylogenet Evol 61: 739-749.

Dung DT, Hop, NT, Thaenkham U, Waikagul J. 2013. Genetic differences among Vietnamese Haplorchis taichui populations using the COI genetic marker. J Helimthol 87: 66-70.

Elderkin CL, Christian AD, Vaughn CC, Metcalfe-Smith JL, Berg DJ. 2007. Population genetics of the freshwater mussel, Amblema plicata (Say 1817) (Bivalvia: Unionidae): Evidence of high dispersal and post-glacial colonization. Conserv Genet 8: 355-372.

Ely B, Stoner DS, Bremer JRA, Dean JM, Addis P, Cau A, Thelen EJ, Jones WJ, Black DE, Smith L, Scott K, Naseri I, Quatrro JM. 2002. Analyses of nuclear IdhA gene and mtDNA control region sequences of Atlantic Northern bluefin tuna populations. Mar Biotechnol 4: 583 588 .

Erikson J, Hohmann G, Boesch C, Vigilant L. 2004. Rivers influence the population genetic structure of bonobos (Pan paniscus). Mol Ecol 13 : 3425-3435.

Esa YB, Siraj SS, Daud SK, Rahim KAA, Japning JRR, Tan SG. 2008. Mitochondrial DNA diversity of Tor tambroides Valenciennes (Cyprinidae) from five natural populations in Malaysia. Zool Stud 47 (3): 360-367.

Esa YB, Suraj SS, Rahim KAA, Daud SK, Chong HG, Guan TS, Syukri MF. 2011. Genetic characterization of two mahseer species (Tor douronensis and Tor tambroides) using microsatellite markers from other Cyprinids. Sains Malays 40 (10): 1087-1095.

Esa Y, Rahim KAA. 2013. Genetic structure and preliminary findings of cryptic diversity of the Malaysian mahseer (Tor tambroides Valenciennes: Cyprinidae) inferred from mitochondrial DNA and microsatellite analyses. BioMed Res Intl 2013: 170980. DOI: 10.1155/2013/170980

Excoffier L, Lischer HEL. 2010. Arlequin suite ver 3.5: A new series of programs to perform population genetics analyses under Linux and Windows. Mol Ecol Resour 10 (3): 564-567.

Fauvelot C, Bernardi G, Planes S. 2003. Reductions in the mitochondrial DNA diversity of coral reef fish provide evidence of population bottlenecks resulting from Holocene sea-level change. Evolution 57 (7): 1571-1583.
Frankham R. 2003. Genetics and conservation biology. CR Biol 326: S22S29

Froese R, Pauly D. 2019. FishBase. World Wide Web electronic publication. www.fishbase.org, version (02/2019).

Garg RK, Sairkar P, Silawat N, Mehrotra NN. 2009. Genetic polymorphism of two populations of catfish Aorichthys seenghala (Sykes) using RAPD fingerprinting. Intl J Integr Biol 7 (3): 130-134.

Garg RK, Sairkar P, Silawat N, Batav N, Mehrotra NN. 2010. Assessment of genetic diversity of Clarias batrachus using RAPD markers in three water bodies of Bhopal. J Environ Biol 31 (5): 749-753.

Gouskov A, Reyes M, Wirthner-Bitterlin L, Vorburger C. 2016. Fish population genetic structure shaped by hydroelectric power plants in the upper Rhine catchment. Evol Appl 9: 394-408.

Hafling B, Weetman D. 2006. Concordant genetic estimators of migration reveal anthropologically enhanced source-sink population structure in the river sculpin, Cottus gobio. Genetics 173: 1487-1501.

Hall TA. 2005. Bioedit: A user-friendly biological sequence alignment editor and analysis program for Windows 95/98/NT. Ibis Therapeutics, A division of Isis Pharmaceuticals 1891 Rutherford Road Carlsbad, CA.

Harris RB, Wall WA, Allendorf FW. 2002. Genetic consequences of hunting: what do we know and what should we do? Wild Soc Bull 30 (2): 634-643.

Hartl DL, Jones EW. 2009. Genetics: Analysis of Genes and Genomes. $7^{\text {th }}$ ed. Jones and Bartlett Publishers, Inc., London.

Hauser L, Adcock GJ, Smith PJ, Ramirez JHB, Carvalho GR. 2002. Lost of microsatellite diversity and low effective population size in an overexploited population of New Zealand snapper (Pagrus auratus). Proc Natl Acad Sci USA 19 (18): 11742-11747.

Hebert PDN, Ratnasingham R, deWaard JR. 2003. Barcoding animal life: cytochrome $\mathrm{c}$ oxidase subunit I divergences among closely related species. Proc R Soc Lond B (suppl.) 270: S96-99.

Hrbek T, Farias IP, Crossa M, Sampaio I, Porto JIR, Meyer A. 2005. Population genetic analysis of Arapaima gigas, one of the largest freshwater fishes of the Amazon basin: implication for its conservation. Anim Conserv 8 (3): 297-308.

Hughes JM, Schmidt DJ, Finn DS. 2009. Genes in streams: using DNA to understand the movement of freshwater fauna and their riverine habitat. BioScience 59: 573-583.

Hutchinson WF, van Oosterhout C, Rogers SI, Carvalho GR. 2003. Temporal analysis of archived samples indicates marked genetic changes in declining North Sea cod (Gadusmorhua). Proc R Soc London B 270: 2125-2132.

Inoue K, Monroe EM, Elderkin CL, Berg DJ. 2014. Phylogeographic and population genetic analyses reveal Pleistocene isolation followed by high gene flow in a wide-ranging, but endangered, freshwater mussel. Heredity 112: 282-290.

Junker J, Peter A, Wagner CE, Mwaiko S, Germann B, Seehausen O, Keller I. 2011. River fragmentation increases localized population genetic structure and enhances asymmetry of dispersal in bullhead (Cottus gobio). Conserv Genet 13: 545-556.

Kamarudin KR, Esa Y. 2009. Phylogeny and phylogeography of Barbonymus schwanenfeldii (Cyprinidae) from Malaysia inferred using partial cytochrome $b$ mtDNA gene. J Trop Biol Conserv 5: 1 13

Kano Y, Vokoun JC, Letcher BH. 2011. Fine-scale population structure and riverscape genetics of brook trout (Salvelinus fontinalis) distributed continuously along headwater channel networks. Mol Ecol 20: 3711-3729.

Kochzius M, Nuryanto A. 2008. Strong genetic population structure in the boring giant clam, Tridacna crocea, across the Indo-Malay Archipelago: implications related to evolutionary processes and connectivity. Mol Ecol 17: 3775-3787

Kochzius M, Seidel C, Hauschild J, Kirchhoff S, Mester P, MeyerWachsmuth I, Nuryanto A, Timm J. 2009. Genetic population structures of the blue starfish Linckia laevigata and its gastropod ectoparasite Thyca crystalline. Mar Ecol Prog Ser 396: 211-219.

Leesa-Nga S, Siraj SS, Daud SK, Tan SG, Harmin SA. 2004. Intraspecific polymorphism in Mystus nemurus (C\&V) detected by RAPD-PCR fingerprinting. Pertanika J. Trop. Agric. Sci. 27 (1): 11- 20.

Liu D, Trumble JT, Stouthamer R. 2006. Genetic differentiation between eastern populations and recent introductions of potato psyllid (Bectericera cockerelli) into western North America. Entomol Exp Appl 118: 177-183.

Liu X, Cao Y, Xue T, Wu R, Zhou Y, Zhou C, Zannata DT, Ouyang S, Wu X. 2017. Genetic structure and diversity of Nodularia douglasiae 
(Bivalvia: Unionida) from the middle and lower Yangtze River drainage. PLoS ONE 12 (12): e0189737. DOI: 10.1371/ journal.pone.0189737

Luttikhuizen PC, Drent J, Baker AJ. 2003. Disjunct distribution of highly diverged mitochondrial lineage clade and population subdivision in marine bivalve with pelagic larval dispersal. Mol Ecol 12: 2215-2229.

Martins C, Wasko AP, Oliveira C, Foresti F. 2003. Mitochondrial DNA variation in wild populations of Leporinus elongatus from the Paraná River basin. Genet Mol Biol 26 (1): 33-38.

Meldgaard T, Nielsen EE, Loeschcke V. 2003. Fragmentation by weirs in a riverine system: A study of genetic variation in time and space among populations of European grayling (Thymallus thymallus) in a Danish river system. Conserv Genet 4: 735-747.

Mohindra V, Ranjana, Khulbe L, Ponniah AG, Lal KK. 2004 Microsatellite loci to assess genetic variation in Tor putitora. J Appl Ichthyol 20 (6): 466-469.

Muflikhah N, Asyari .2007. Pemeliharaan ikan baung (Mystus nemurus) dalam berbagai lingkungan dan sistem wadah budi daya. Media Akuakultur 2: 71-76. [Indonesian]

Muneer MA, Gopalakrishnan A, Musammilu KK, Mohindra V, Lal KK, Basheer VS, Lakra WS. 2009. Genetic variation and population structure of endemic yellow catfish, Horabagrus brachysoma (Bagridae) among three populations of Western Ghat region using RAPD and microsatellite markers. Mol Biol Rep 36 (7): 1779-1791.

Muschick M, Indermaur A, Salzburger W. 2012. Convergent evolution within an adaptive radiation of cichlid fishes. Curr Biol 22: 23622368.

Nei M. 1987. Molecular Evolutionary Genetics. Columbia University Press, New York

Nei M, Jin L. 1989. Variances of the average numbers of nucleotide substitutions within and between populations. Mol Biol Evol 6: 290300.

Nguyen TTT. 2008. Population structure in the highly fragmented range of Tor douronensis (Cyprinidae) in Sarawak, Malaysia revealed by microsatellite DNA markers. Freshw Biol 53: 924-934.

Nugroho E, Hadie W, Subagja J, Kurniasih T. 2005. Keragaman genetik danmorfometrik pada ikan baung, Mystus nemurus dari Jambi, Wonogiri,dan Jatiluhur. Jurnal Penelitian Perikanan Indonesia 11 (7): 1-6. [Indonesian]

Nugroho E, Hadie W, Sudarto. 2003. Variasi geneetik ikan baung, Mystus nemurus dari beberapa waduk di Jawa yang dianalisis dengar mitokondria d-loop. Jurnal Penelitian Perikanan Indonesia 9 (1): 1-5 [Indonesian]

Nuryanto A, Setyaningrum N. 2008. Intraspecific genetic diversity of senggaringan (Mystus nigriceps) in the Serayu River based on enzymes electrophoresis data. Sains Akuatik 11 (2): 100-108.

Nuryanto A, Kochzius M. 2009. Highly restricted gene flow and deep evolutionary lineages in the giant clam Tridacna maxima. Coral Reefs 28: 607-619.

Nuryanto A, Bhagawati M, Abulias MN, Indarmawan. 2012. Fish diversity at Cileuleuh River in District of Majenang, Cilacap Regency, Central Java. Jurnal Iktiologi Indonesia 12 (2): 147-153.

Nuryanto A, Qonita NH, Pramono H, Kusbiyanto, Soedibja PHT. 2017. Genetic variation in cytochrome b-Hinf 1 and -Alu1 gene correlated to body size in Soang Gourami (Osphronemus goramy) from single spawning. Biosaintifika 9 (2): 185-192.

Nuryanto A, Amalia G, Khairani D, Pramono H, Bhagawati D. 2018. Molecular characterization of four giant gourami strains from Java and Sumatra. Biodiversitas 19 (2): 528-539.

Olsen JB, Crane PA, Flannery BG, Dunmall K, Templin WD, Wenburg JK. 2010. Comparative landscape genetic analysis of three Pacific salmon species from subarctic North America. Conserv Genet 12 (1): 223-241.

O'reilly PT, Canino MF, Bailey KM, Bentzen P. 2004. Inverse relationship between $F_{\mathrm{ST}}$ and microsatellite polymorphism in the marine fish, walleye pollock (Theragra chalcogramma): implications for resolving weak population structure. Mol Ecol 13: 1799-1814.

Pappalardo AM, Cuttitta A, Sardella A, Musco M, Maggio T, Patti B, Mazzola S, Ferrito V. 2015. DNA barcoding and COI sequence variation in Mediterranian lanternfishes larvae. Hydrobiologia 749 155-167.

Parmaksiz A, Eksi E. 2017. Genetic diversity of the cyprinid fish Capoeta trutta (Heckel, 1843) populations from Euphrates and Tigris rivers in Turkey based on mtDNA COI sequences. Indian J Fish 64 (1): 18-22.

Pavesi L, De Matthaeis E, Tiedemann R, Ketmaier V. 2011. Temporal population genetics and COI phylogeography of the sandhopper
Macarorchestia remyi (Amphipoda: Talitridaae). Zool Stud 50 (2): 220-229.

Purcell JFH, Cowen RK, Hughes CR, Williams DA. 2006. Weak genetic structure indicates strong dispersal limits: a tale of two coral reef fish. Proc R Soc Lond B 273: 1483-1490.

Putro SS. 2003. Ecology of green catfish (Mystus nemurus C.V.) in Klawing River Purbalingga Regency and Factors Related to its Domestication. [Thesis]. Program of Environmental Sciences, Graduate School, Jenderal Soedirman University, Purwokerto. [Indonesian]

Raeymaekers JAM, Raeymaekers D, Koizumi I, Geldof S, Volckaert FAM. 2009. Guidelines for restoring connectivity around water mills: a populations genetic approach to the management of riverine fish. $\mathrm{J}$ Appl Ecol 46: 562-571.

Rogers AR. 1995. Genetic evidence for Pleistocene population expansion. Evolution 49: 608-615.

Rogers A, Harpending H. 1992. Population growth makes waves in the distribution of pairwise genetic differences. Mol Biol Evol 9: 552569.

Excoffier L, Lischer HEL. 2010. Arlequin suite ver 3.5: A new series of programs to perform population genetics analyses under Linux and Windows. Mol Ecol Resour 10 (3): 564-567.

Sabando MC, Vila I, Penaloza R, Veliz D. 2011. Contrasting population genetic structure of two widespread aquatic insects in the Chilean high-slope rivers. Mar Freshw Res 62: 1-10.

Santos MCF, Ruffino ML, Farias IP. 2007. High levels of genetic variability and panmixia of the tambaqui Colossoma macropomum (Cuvier, 1816) in the main channel of the Amazon River. J Fish Biol 71 (Supplement X): 1-12.

Shefer S, Abelson A, Mokady O, Geffen E. 2004. Red to Mediterranean Sea bioinvasion: natural drift through the Suez Canal, or anthropogenic transport? Mol Ecol 12: 2333-2343.

So N, Van Houdt JKJ, Volckaert FAM. 2006. Genetic diversity and population history of the migratory catfishes Pangasianodon hypophthalmus and Pangasius bocourti in the Cambodian Mekong River. Fish Sci 72: 469-476.

Song LM, Munian K, Rashid ZA, Bhassu S. 2013. Characterisation of Asian snakehead murrel Channa striata (Chanidae) in Malaysia: An insight into molecular data and morphological approach. Sci World J 2013: 917506. DOI: 10.1155/2013/917506.

Stern DL. 2013. The genetic causes of convergent evolution. Nat Rev Genet | AOP, published online 9 October 2013; doi: 10.1038/nrg3483.

Stockley B, Menezes G, Pinho MR, Rogers AD. 2005. Genetic population structure in the black-spot sea bream (Pagellus bogaraveo Brunnich, 1768) from the NE Atlantic. Mar Biol 146: 793-804.

Sugama K, Haryanti, Benzie JAH, Ballment E. 2002. Genetic variation and population structure of the giant tiger prawn, Penaeus monodon, in Indonesia. Aquaculture 205: 37-48

Thompson JG, Higgins DG, Gibson TJ. 1994. ClustalW: improving the sensitivity of progressive multiple sequence alignments through sequence weighting, position-specific gap penalties and weight matrix choice. Nucleic Acids Res 22: 4673-4680.

Unmack PJ. 2001. Biogeography of Australian freshwater fishes. J Biogeogr 28:1053-1089.

Wang C, Yu X, Tong J. 2007. Microsatellite diversity and population genetic structure of redfin culter (Culter erythropterus) in fragmented lakes of the Yangtze River. Hydrobiologia 586: 321-329.

Ward RD, Zemlak TS, Innes BH, Last PR, Hebert PDN. 2005. DNA barcoding Australia's fish species. Phil Trans R Soc B 360: 18471857.

Yan R-J, Zhang G-R, Guo X-Z, Ji W, Chen K-C, Zou G-W, Wei K-J, Gardner JPA. 2017. Genetic diversity and population structure of the northern snakehead (Channa argus Channidae: Teleostei) in central China: implications for conservation and management. Conserv Genet. DOI: 10.1007/s10592-017-1023-x.

Yang L, He S. 2008. Phylogeography of the freshwater catfish Hemibagrus guttatus (Siluriformes, Bagridae): Implications for South China biogeography and influence of sea-level changes. Mol Phylogenet Evol 49: 393-398.

Yang L, Mayden RL, He S. 2009. Population genetic structure and geographical differentiation of the Chinese catfish Hemibagrus macropterus (Siluriformes, Bagridae): Evidence for altered drainage patterns. Mol Phylogenet Evol 51: 405-411.

Zanatta DT, Murphy RW. 2007. Range-wide population genetic analysis of the endangered northern riffleshell mussel, Epioblasma torulosa rangiana (Bivalvia: Unionoida). Conserv Genet 8: 1393-1404. 
Zhang Q, Allen Jr SK, Reece KS. 2005. Genetic variation in wild and hatchery stocks of suminoe oyster (Crassostrea ariakensis) assessed by PCR-RFLP and microsatellite markers. Mar Biotechnol 7: 588599.

Zhang G-H, Yuan Z-J, Zhang C-X, Yin K-S, Tang M-J, Guo H-W, Fu JY, Xiao Q. 2014. Detecting deep divergence in seventeen populations of tea geometrid (Ectropis obliqua Prout) in China by COI mtDNA and cross-breeding. PLoS ONE 9 (6): e99373. DOI: 10.1371/journal.pone.0099373.

Zhong L, Song C, Wang M, Chen Y, Qin Q, Pan J, Chen X. 2013. Genetic diversity and population structure of yellow catfish Pelteobagrus fulvidraco from five lakes in the middle and lower reaches of the Yangtze River, China, based on mitochondrial DNA control region. Mitochondrial DNA 24 (5): 552-558. 